\title{
Hubungan Kadar Docosahexaenoic Acid Terhadap Perlemakan Hati Non Alkoholik Remaja Obesitas
}

\author{
Dhina Lidya Lestari,,${ }^{1}$ Yusri Dianne Jurnalis, ${ }^{1}$ Gustina Lubis,,${ }^{1}$ Hirowati $A l i,{ }^{2}$ Yorva Sayoeti ${ }^{1}$ \\ *Departemen Ilmu Kesehatan Anak Fakultas Kedokteran Universitas Andalas/RSUP dr. M. Djamil Padang \\ **Pasca sarjana Ilmu Biomedik Fakultas Kedokteran Universitas Andalas
}

\begin{abstract}
Latar belakang. Penyakit hati berlemak non alkohol (NAFLD) adalah penyakit yang ditandai dengan timbunan lemak yang signifikan di hepatosit dari parenkim hati yang menyebabkan kerusakan hati berupa peradangan. Prevalensi NAFLD meningkat seiring dengan meningkatnya obesitas pada anak dan remaja. Docosahexaenoic acid (DHA) merupakan salah satu pengobatan farmakologis untuk NAFLD dan belum ada data terbaru yang spesifik untuk pengukuran DHA pada anak NAFLD.

Tujuan. Menganalisis hubungan DHA dengan NAFLD , dan mengukur nilai DHA setiap derajat NAFLD.

Metode. Lima puluh delapan remaja obesitas (31 laki-laki, 27 perempuan), berusia 14-18 tahun yang terpantau di kota Padang, sejak Juni - Juli 2017. Penelitian ini bersifat observasional cross sectional.

Hasil. Tidak ada perbedaan jenis kelamin yang diamati pada NAFLD. Indeks massa tubuh pada kelompok NAFLD lebih tinggi daripada non-NAFLD $30,30 \pm 4,21 \mathrm{~kg} / \mathrm{m} 2$ vs $28,70 \pm 2,65 \mathrm{~kg} / \mathrm{m} 2$. Pengukuran derajat penyakit perlemakan hati non alkohol dengan hasil USG masingmasing derajat ringan, sedang dan berat adalah 12(37,5\%), 15(46,8\%) dan 5(15,6\%). Selain itu, kandungan DHA memiliki perbedaan yang signifikan pada masing-masing kelompok, penyakit perlemakan hati non-alkohol vs non-NAFLD 40,46 $\pm 19,23$ menjadi 89,26 $\pm 41,21 \mu \mathrm{g} /$ $\mathrm{ml}$ dengan $\mathrm{p}<0,0001$.

Kesimpulan. Nilai DHA signifikan lebih rendah pada kelompok penyakit hati berlemak non alkohol yang dikonversi dengan non-NAFLD. Manajemen diet dengan DHA tinggi penting untuk mencegah dan mengelola obesitas dengan lebih baik. Sari Pediatri 2021;23(2):82-7
\end{abstract}

Kata kunci: docosahexaenoic acid, perlemakan hati non alkoholik, remaja, obesitas

\section{The Relationship of Docosahexaenoic Acid with Non Alcoholic Fatty Liver Disease}

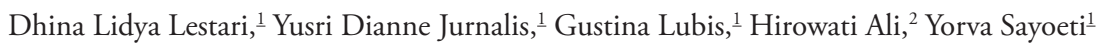

Background. Non alcoholic fatty liver disease (NAFLD) is a disease characteritized by significant fat deposits in hepatocytes from liver parenchym causing liver damage in the form of inflammation. The prevalence of NAFLD increases along with the rising of obesity in children and adolescent. Docosahexaenoic Acid (DHA) is one of farmacologic treatment for NAFLD and no recently data which spesific to measurement DHA in NAFLD children.

Objective. To analyze the relationship of DHA with NAFLD, and to measurement value of DHA each degree of NAFLD.

Methods. Fifty -eight obese adolescent (31 male, 27 female), aged 14-18 years. This observational cross sectional study. Observed in Padang city, since June -July 2017.

Result. No sex difference was observed in NAFLD. Body mass Index in NAFLD group was higher than non- NAFLD 30,30 $\pm 4,21 \mathrm{~kg} / \mathrm{m}^{2}$ vs $28,70 \pm 2,65 \mathrm{~kg} / \mathrm{m}^{2}$. Non alcoholic fatty liver disease degree measurement with Ultrasounography result each degree mild, moderate and severe were $12(37,5 \%), 15(46,8 \%)$ and $5(15,6 \%)$. In addition, DHA content had sicnificant differentiated each group, Non alcoholic fatty liver disease vs non- NAFLD $40,46 \pm 19,23$ to $89,26 \pm 41,21 \mu \mathrm{g} / \mathrm{ml}$ with $\mathrm{p}<0,0001$.

Conclusion. DHA value significant lower in Non alcoholic fatty liver disease group convert with non-NAFLD. Dietary management with high DHA were important to prevent and better manage obesity. Sari Pediatri 2021;23(2):82-7

Key word: docosahexaenoic acid, non alcoholic fatty liver disease, adolescent, obese 
$\mathrm{P}$ erlemakan hati adalah penumpukan lemak $5 \%$ dari berat normal hati, sering ditemukan pada obesitas dan peminum alkohol, tetapi dapat juga ditemukan pada keadaan tanpa mengonsumsi alkohol (NAFLD/non alcoholic fatty liver disease). ${ }^{1,2}$

Kumpulan gejala klinis dan kriteria patologis NAFLD, berupa spektrum kerusakan hati, mulai dari yang paling ringan NASH (non alcoholic steatohepatitis), fibrosis, sirosis hingga stadium akhir berupa karsinoma hepatoselluler. ${ }^{5}$ Perlemakan hati dapat diketahui melalui pemeriksaan pencitraan atau gambaran histologi. Penyakit ini merupakan penyebab penting terjadinya penyakit hati kronis dan faktor risiko mayor pada penyakit kardiovaskuler. ${ }^{1,3,4}$

Proses terjadinya NAFLD tidak begitu jelas, tetapi peningkatannya juga menyertai meningkatnya risiko perlemakan pada pembuluh darah, penyakit kardiovaskuler dan angka kematian yang tinggi bila dibandingkan dengan populasi normal., 6

Pasien yang telah mengalami perlemakan hati di usia yang lebih muda maka komplikasi dari penyakit hati dan sindrom metabolik akan lebih cepat terjadi. Tatalaksana awal untuk NAFLD adalah dengan mengurangi berat badan. Hal ini menyebabkan perlu adanya suatu upaya deteksi lebih awal terhadap NAFLD terutama remaja obesitas. Selain itu pengaturan diet juga sama pentingnya dengan olahraga dan memperbaiki gaya hidup. ${ }^{3,7}$

Data terakhir dari National Health Nutrition Examination Survey (NHANES) menunjukkan 17\% anak mengalami kegemukan dan $70 \%$ hingga $80 \%$, di antaranya adalah NAFLD. Populasi NAFLD di negara berkembang sekitar 10-24\% dari seluruh populasi, 30\% di antaranya laki-laki dan 52,8\% pada obesitas. Data penelitian penyakit ini di Indonesia belum banyak. 3,8 Febianne $\mathrm{dkk}^{17}$ pada tahun 2015 memdapatkan peningkatan SGOT $57,1 \%$ pada sample laki-laki dan $18,75 \%$ pada perempuan.

Manifestasi klinis NAFLD adalah asimptomatis. Namun, sebagian pasien mengeluh terdapat rasa tidak nyaman pada abdomen kanan atas, diduga berhubungan dengan distensi atau peregangan kapsul hati. Pemeriksaan fisik tidak ditemukan adanya gambaran penyakit hati menahun, sedangkan hepatomegali ditemukan pada $50 \%$ pasien pada tahap awal. ${ }^{8}$

Berbagai terapi telah digunakan dalam tatalaksana NAFLD, Beberapa terapi yang pernah dikemukakan untuk tatalaksana NAFLD, antara lain, Omega-3, metformin, thiazolidinedione, Vitamin E, ursodeoxycholic acid, Probucol, Carnitin, Betaine dan Probiotik, bahkan juga dilaporkan tindakan Bariatrik. ${ }^{4,9,10,11}$

Terapi farmakologi tidak begitu berhasil. Penggunaan obat-obatan dosis tinggi terutama pada anak tidak dianjurkan. ${ }^{7}$ Omega-3 merupakan suplemen diet yang aman dan menunjukkan efektivitas yang tinggi untuk preventif dan terapi NAFLD, penyakit kardiovaskular, dislipidemia dan penyakit metabolik. Capanni $\mathrm{dkk}^{12}$ memberikan Omega-3 pada 56 pasien NAFLD, terdapat penurunan pada hasil pemeriksaan enzim hati. Begitu pula Nobili $\mathrm{dkk}^{13}$ yang juga mendapatkan hasil serupa.

Penelitian ini membandingkan kadar DHA dengan kejadian NAFLD pada remaja dengan obesitas. Docosahexaenoic acid dipilih karena Docosahexaenoic acid (DHA) itu sendiri merupakan bentuk akhir dari sistem metabolisme omega-3 dan DHA dianggap bentuk tertinggi dan stabil dalam serum. Docosahexaenoic acid atau DHA merupakan salah satu bentuk asam lemak Omega-3 yang tidak diproduksi oleh tubuh. ${ }^{14}$

Penelitian ini ditujukan untuk menilai kadar Docosahexaenoic Acid (DHA) serum pada remaja dengan NAFLD, dengan dugaan kadar DHA akan rendah pada keadaan tersebut.

\section{Metode}

Penelitian ini merupakan suatu penelitian cross sectional. Penelitian dilakukan terhadap remaja SMU Kota Padang dan laboratorium Biomedik FK. Universitas Andalas Padang serta bagian Radiologi RS. Aisyiyah Padang, dimulai pada bulan desember 2016 sampai bulan Juli 2017. Populasi penelitian adalah remaja obesitas yang bersekolah di Sekolah Menengah Umum (SMU) di kota Padang. Sampel pada penelitian ini adalah bagian dari populasi yang memenuhi kriteria inklusi. Sampel terbagi dalam dua kelompok, yaitu kelompok kontrol atau Non-NAFLD dan NAFLD. Jumlah sampel minimal masing-masing kelompok 23 orang, dengan kemungkinan drop out $10 \%$ menjadi 26 orang. Metode pengambilan sampel dengan cara consecutive sampling, dengan subjek merupakan remaja obesitas di tingkat SMU kota Padang. Subjek dipilih yang memenuhi kriteria inklusi di beberapa SMU kota Padang. 


\section{Hasil}

Karakteristik sampel penelitian tertera pada Tabel 1 di bawah ini. Berdasarkan Tabel 1 didapatkan bahwa tidak ada perbedaan sebaran jenis kelamin baik pada kelompok kontrol ataupun kelompok NAFLD. Rata-rata umur pada kedua kelompok relatif sama karena subjek yang diambil pada penelitian ini adalah kelompok usia remaja 14-18 tahun. Nilai BMI pada kelompok yang mengalami NAFLD lebih tinggi dibandingkan kelompok kontrol.

Tabel 2 memperlihatkan bahwa adanya perbedaan kadar rerata DHA yang signifikan $(\mathrm{p}<0,05)$ antara kelompok NAFLD dengan kelompok kontrol.

Tabel 3 memperlihatkan bahwa terdapat perbedaan kadar DHA di setiap derajat perlemakan hati. Derajat perlemakan hati yang paling tinggi adalah derajat III, nilai rerata DHA paling rendah. Hasil pada Tabel 3 ini kemudian di uji dengan uji Post $H o c$, dan didapatkan bahwa terdapat perbedaan signifikan $(\mathrm{p}<0,05)$ antara kelompok derajat 1 dengan kelompok derajat 3 , begitu juga kelompok derajat 2 dengan derajat 3.

\section{Pembahasan}

Hasil penelitian didapatkan tidak ada perbedaan jenis kelamin antara kedua kelompok kontrol maupun perlemakan hati non alkoholik, begitu juga dengan umur, berat badan, tinggi badan dan BMI. Penelitian sebelumnya oleh Chan $\mathrm{dkk},{ }^{15}$ mendapatkan gambaran perlemakan hati pada remaja perempuan 68\% dibanding laki-laki $81 \%$. Sementara Saki $\mathrm{dkk}^{16} \mathrm{di}$ Iran melaporkan perlemakan hati non alkoholik lebih banyak pada anak perempuan $(64,7 \%)$ dengan rentang usia 5-17 tahun. Penelitian Febianne dkk ${ }^{17}$ melaporkan $83,7 \%$ perlemakan hati pada anak perempuan.

Nilai BMI pada kelompok perlemakan hati non alkoholik didapatkan lebih tinggi dibandingkan kelompok kontrol, yaitu $30,30 \pm 4,21 \mathrm{~kg} / \mathrm{m}^{2}$ dibanding $28,70 \pm 2,65 \mathrm{~kg} / \mathrm{m}^{2}$. Penelitian Zhang $\mathrm{dkk}^{18}$ melaporkan usia rerata perlemakan hati non alkoholik $12,3 \pm 3,4$

Tabel 1. Karakteristik subjek penelitian

\begin{tabular}{lcc}
\hline Karakteristik & $\begin{array}{c}\text { Kontrol } \\
\mathrm{n}=26\end{array}$ & $\begin{array}{c}\text { NAFLD } \\
\mathrm{n}=32\end{array}$ \\
\hline Jenis kelamin (\%) & & \\
$\quad$ Laki-laki & $16(61,5)$ & $15(46,8)$ \\
$\quad$ Perempuan & $10(38,46)$ & $17(53,1)$ \\
Umur(th) (SB) & $15,73(0,87)$ & $15,5(0,84)$ \\
Berat badan(kg) (SB) & $71,6(7,74)$ & $71,75(9,51)$ \\
Tinggi badan $(\mathrm{cm})(\mathrm{SB})$ & $158,0(5,96)$ & $154,03(4,58)$ \\
BMI $\left(\mathrm{kg} / \mathrm{m}^{2}\right)(\mathrm{SB})$ & $28,70(2,65)$ & $30,30(4,21)$ \\
\hline
\end{tabular}

Tabel 2. Perbedaan kadar rerata DHA pada kelompok kontrol dengan perlemakan hati non alkoholik

\begin{tabular}{lcc}
\hline Kelompok & $\begin{array}{l}\text { Kadar DHA } \\
(\mu \mathrm{g} / \mathrm{dl})(\mathrm{SD})\end{array}$ & $\mathrm{p}$ \\
\hline NAFLD & $40,4(19,23)$ & 0,0001 \\
Kontrol & $89,26(41,21)$ & \\
\hline
\end{tabular}

Tabel 3. Gambaran hubungan kadar rerata DHA terhadap derajat perlemakan hati

\begin{tabular}{lccc}
\hline Kelompok & Jumlah & Kadar DHA (SD) & $\mathrm{p}$ \\
\hline Derajat I & 12 & $38,87(11,99)$ & 0,0001 \\
Derajat II & 15 & $50,59(17,66)$ & \\
Derajat III & 5 & $13,88(10,11)$ & \\
\hline
\end{tabular}


tahun dengan BMI 19,5 $\pm 3,9 \mathrm{~kg} / \mathrm{m}^{2}$. Sementara Catherine dkk ${ }^{19}$ melaporkan nilai BMI $39,4 \pm 13,5 \mathrm{~kg} /$ $\mathrm{m}^{2}$ pada anak dengan perlemakan hati non alkoholik dengan rentang umur $14,0 \pm 2,8$ tahun.

Komplikasi NAFLD lazim terjadi pada anak dengan obesitas dengan karakteristik peningkatan metabolisme lemak, steatosis makrovaskular hati. Baku emas untuk pemeriksaan perlemakan hati adalah biopsi hati. Metode ini sangat invasif dan memberikan rasa tidak nyaman terhadap subjek perlakuan sehingga tidak dipilih menjadi metode penelitian ini. Sebagai gantinya, penelitian ini menggunakan pemeriksaan ultrasonografi (USG) hati yang juga dapat digunakan untuk menentukan derajat perlemakan hati. Metode ini dipilih karena non invasif dan nilai sensitivitas $89 \%$ serta spesifisitas 93\%. Pemeriksaan USG dilakukan oleh satu orang ahli radiologi. Hal ini merupakan salah satu keterbatasan penelitian ini sehingga tidak adanya pembanding dari hasil bacaan USG dari semua subjek yang diperiksa. Kriteria USG untuk menentukan perlemakan hati, yaitu gambaran hepatorenal echo contrast, hiperechoic (bright liver), serta blurring pembuluh darah yang dilihat pada parenkim hati dan diafragma. Penelitian ini mendapatkan perlemakan hati derajat I (mild), derajat II (moderate) dan III (severe) secara berturut-turut 12 (37,5\%), 15 (46,8\%) dan 5 (15,6\%) orang. Chan dkk ${ }^{15}$ melaporkan 77\% (65 subjek dari 84)kelompok anak obesitas dengan perlemakan hati. Masing-masing derajat perlemakan hati berdasarkan USG yang ditemukan mulai dari mild $38 \%$, moderate $24 \%$, dan severe $16 \%$. Febianne $\mathrm{dkk}^{17}$ melaporkan hasil pemeriksaan USG hati pada anak obesitas, dengan derajat perlemakan hati I, II, dan III secara berturut-turut 64\%, 20,5\%, dan 15,2\%.

Omega-3 pada manusia biasanya hanya sedikit yang diubah dari asam alpha-linolenic/ALA menjadi asam eicosapentaenoic/EPA (bentuk awal yang didapat dari makanan). Hal ini dikarenakan oleh aktivitas delta-6 desaturase terbatas. Perubahan ALA menjadi DHA hanya $5 \%$. Oksidasi dari ALA yang dikonsumsi sekitar $25 \%$ diubah dan meningkat $60 \%$ setelah 7 hari. ${ }^{20} \mathrm{Hal}$ ini yang mungkin terjadi pada salah satu subjek dengan hasil pemeriksaan USG hanya mengalami perlemakan hati derajat 1 , tetapi hasil pemeriksaan kadar DHA serum sangat rendah, yaitu $13,76 \mu \mathrm{g} / \mathrm{ml}$. Nilai DHA rendah kemungkinan disebabkan faktor lain, seperti jumlah asupan DHA sangat kurang atau aktivitas enzim delta- 6 desaturase yang terbatas.

Terdapat perbedaan kadar DHA yang signifikan antara kelompok NAFLD dengan yang tidak mengalami
NAFLD, yaitu 40,46 $\pm 19,23 \mu \mathrm{g} / \mathrm{ml}$ dan $89,26 \pm 41,21 \mu \mathrm{g} /$ $\mathrm{ml}$. Nilai DHA terendah dan tertinggi pada kelompok yang tidak mengalami NAFLD adalah 16,92 $\mu \mathrm{g} /$ $\mathrm{ml}$ dan $172,27 \mu \mathrm{g} / \mathrm{ml}$. Sebaliknya, pada kelompok dengan NAFLD nilai terendah dan tertingginya secara berturut-turut adalah 3,98 $\mu \mathrm{g} / \mathrm{ml}$ dengan 69,64 $\mu \mathrm{g} /$ ml. Silvia $\mathrm{dkk}^{21}$ mengukur kadar DHA dalam asam lemak plasma pada anak obesitas dan melaporkan $1,5(0,5)(\mathrm{W} / \mathrm{W} \%)$ dan anak dengan berat badan normal $1,7(0,7)(\mathrm{W} / \mathrm{W} \%)$. Emiko $\mathrm{dkk}^{22}$ menilai kadar DHA dengan asam lemak pada anak obesitas dengan hasil 6,8 $\pm 1,0$ (W/W\%) pada anak laki-laki dan $6,4 \pm 1,8(\mathrm{~W} / \mathrm{W} \%)$ pada anak perempuan. Masih dari hasil penelitian Emiko dkk melaporkan kadar DHA yang rendah pada anak dengan sindrom metabolik, yaitu 5,9 $\pm 1,0(\mathrm{~W} / \mathrm{W} \%)$ dibandingkan anak dengan obesitas tanpa sindrom metabolik 6,8 $\pm 1,1$ (W/W\%). Terdapat perbedaan nilai DHA pada penelitian ini dengan penelitian sebelumnya dikarenakan perbedaan metode yang digunakan. Penelitian ini menggunakan metode ELISA dengan satuan hasil $\mu \mathrm{g} / \mathrm{ml}$ dan tidak dibandingkan kadarnya dengan kadar asam lemak total.

Kadar rerata DHA serum pada kelompok derajat perlemakan hati 2 lebih tinggi bila dibandingkan dengan derajat 1 . Hal ini mungkin disebabkan karena adanya hasil kadar DHA pada kelompok derajat 1 yang lebih rendah, bahkan masih di bawah rerata pada kelompok derajat 3, yaitu $13,76 \mu \mathrm{g} / \mathrm{ml}$. Perbedaan inilah yang nantinya akan menyebabkan besarnya nilai standar deviasi.

Penelitian ini tidak mempertimbangkan jumlah konsumsi makanan yang mengandung Omega-3 sebelum subjek diperiksa. Penelitian terdahulu menemukan fakta bahwa konsumsi Omega-3, baik yang berasal dari makanan ataupun suplemen dapat memengaruhi konsentrasi EPA dan DHA di membran sel yang nantinya akan berpengaruh terhadap terjadinya NAFLD. ${ }^{23}$ Sebuah penelitian di Toronto Amerika dilaporkan bahwa adanya hubungan yang kuat antara konsumsi EPA dan DHA dengan nilai alannine aminotransferase (ALT). ${ }^{24}$ Meskipun jumlah konsumsi ikan dan rantai panjang asam lemak tak jenuh omega 3 tidak berhubungan langsung dengan diagnosis $\mathrm{NASH}$, proses inflamasi diketahui sebagai predisposisi terjadinya fibrosis dan perburukan pada penyakit hati anak dan remaja. kegagalan dalam mencari hubungan ini mungkin disebabkan oleh fakta bahwa parameter hitologi steatohepatitis dari hasil biopsi pada anak dan remaja tidak begitu dipahami seperti pada dewasa. ${ }^{25}$ 
Pola makan pada penderita NAFLD adalah berlebihan dalam mengonsumsi fruktosa, minuman ringan, daging, lemak jenuh dan kolesterol serta sedikit mengkonsumsi serat, Omega-3 dan vitamin E. Pola makan tersebut tidak ditelaah dalam penelitian ini. Intervensi nutrisi sebenarnya memiliki peran penting pada penderita NAFLD. Selain itu, gaya hidup dan olahraga juga merupakan salah satu faktor yang memengaruhi derajat NAFLD. Penelitian terdahulu yang meneliti subjek dengan mengubah gaya hidup selama 12 bulan dengan intervensi diet serta meningkatkan aktivitas fisik dapat menurunkan berat badan $4,75 \mathrm{~kg}$ dan berkaitan signifikan pada perbaikan histologi dan laboratorium fungsi hati pada anak dengan NAFLD.

Subjek yang terlibat pada penelitian ini tidak dilakukan pengukuran lingkar perut-pinggul yang dapat menilai adanya obesitas sentral terutama obesitas viseral. Subjek tidak dibedakan berdasarkan jenis obesitasnya, apakah termasuk jenis obesitas sentral atau tidak. Penelitian obesitas pada dewasa yang mengalami obesitas sentral menunjukkan adanya pengaruh negatif kadar total serum lemak dengan kadar lemak tak jenuh rantai panjang Omega-3. Kadar serum lemak tersebut Apo B dan triacylglycerol. ${ }^{26}$

Penelitian ini tidak mendata riwayat konsumsi omega-3 dalam hal ini DHA pada subjek dan tidak dibandingkan dengan nilai rerata BMI yang telah didapatkan. Sebuah penelitian meta-analisis pada dewasa dengan obesitas mendapatkan tidak adanya pengaruh yang signifikan terhadap asupan minyak ikan yang dipercaya banyak mengandung Omega-3 dengan nilai rerata BMI, lingkar pinggul dan berat badan. ${ }^{27}$ Keterbatasan penelitian lainnya adalah jumlah sampel yang terbatas, dan pada penelitian ini hanya memeriksa satu derivat bentuk omega-3 saja, yaitu DHA. Hal ini disebabkan keterbatasan alat yang digunakan dan biaya penelitian yang akan menjadi sangat mahal bila dilakukan pemeriksaan pada berbagai bentuk derivat omega-3 dan pemeriksaan derajat NAFLD dengan menggunakan USG hanya dilakukan oleh satu orang ahli radiologi.

\section{Kesimpulan}

Kadar rerata DHA pada remaja obesitas dengan NAFLD lebih rendah secara signifikan dibandingkan dengan yang non-NAFLD. Semakin berat derajat perlemakan hati (Derajat III), maka kadar DHA akan semakin rendah dan perbandingan ini bermakna secara signifikan. Perlu dilakukan penelitian lebih lanjut dengan melakukan penilaian asupan DHA sebelum pemeriksaan.

\section{Daftar pustaka}

1. Schiff L, Schiff ER. Fatty liver. Biochem Clin Aspects 1995;825-55.

2. Edmison J, McCullough AJ. Pathogenesis of Non-alcoholic. Steatohepatitis: human data. Clin Liver Dis 2007;11:75-104.

3. Minno MN, Russolillo A, Lupoli R, dkk. Omega-3 Fatty Acids for the treatment of non-alcholic fatty liver disease. World J Gastroenterol 2012;18:5839-47.

4. McCarthy EM, Rinella ME. The Role of Diet and Nutrient Compositionin Non alcoholic Fatty Liver Disease. J Acad Nutr Dietet 2012:401-9.

5. Dowman JK, Tomlinson JW, Newsome PN. pathogenesis of non-alcoholic fatty liver disease. Q J Med 2009;103:71-83.

6. Vos MB, McClain CJ. Nutrition and nonalcoholic fatty liver disease in children. Current Gastroenterol Reports 2008;10:308-15.

7. Janczyk W, Socha P, Lebensztejn D, dkk. Omega-3 fatty acids for treatment of non-alcoholic fatty liver disease: design and rationale of randomized controlled trial. BMC Pediatrics 2013;13:1-11.

8. Amarapurkar D. NAFLD and NASH Asian perspective. Trop Gastroenterol 2011:23-6.

9. Chalasani N, Younossi Z, Lavine JE, , dkk. The diagnosis and management of non-alcoholic fatty liver disease practice guideline by the American Association for the Study of Liver Diseases American College of Gastroenterology, and The American Gastroenterological Association. Hepatology 2012;55:2005-23.

10. Tan H-H, Chang P-E. Non-alcoholic Fatty Liver Disease. In: Department of Gastroenterology and Hepatology SGH, Singapore. 2010;19:36-50.

11. Vos MB, McClain CJ. Nutrition and nonalcoholic fatty liver disease in children. Curr Gastroenterol Rep 2008;10:308-15

12. Capanni, Calella, Biagini MR, S. Genise, L. Raimondi. Prolonged n-3 polyunsaturated fatty acid supplementation ameliorates hepatic steatosis in patients with non-alcoholic fatty liver disease:a pilot study. Alimentary Pharmacol Therapeut 2006;23:1143-51.

13. Nobili V, Bedogni G, alisi A, dkk. Docosahexaenoic acid supplementation decreases liver fat content in children with non-alcoholic fatty liver disease. BMJ. 2011: 350-3.

14. Surette ME. The science behind dietary omega-3 fatty acids. CMAJ 2008;178:177-9.

15. Chan DFY, Li A, Chu WCW, dkk. Hepatic steatosis in obese Chinese children. International J Obes 2004;28:1257-62. 
16. Saki F, Karamizadeh Z. Metabolic syndrome, insulin resistence and fatty liver in ibese Iranian children. Iran Red Crescent Med J 2014;16:1-5.

17. Febianne E, Yusri DJ, Hirowati A, Hafni B, Rozetti. Hubungan kadar serum aminotransferase dengan derajat perlemakan hati pada remaja obesitas di kota Padang [Tesis] Padang: Fakultas Kedokteran Universitas Andalas,2015.

18. Zhang X, Wan Y, Zhang S, dkk. Non Akcoholic fatty liver disease prevalence in urban school aged children and adolescents from the Yangtze River delta region: a cross sectional study. Asia Pac J Clin Nutr 2015;24:281-8.

19. Catherine EC, Jean AW, Rebecca LC, , dkk. Natural history of NAFLD diagnosed in childhood: A single-center study. Children 2017;4:1-11.

20. Collins JJ. Omega-3 Essential Fatty Acids. Nutri News 2010; 9:1-8.

21. Silvia S, Elvira V, Michela S, dkk. Plasma long-chain fatty acids and the degree of obesity in Italian children.Acta Paed 2006;95:964-9.

22. Emiko S, Tommo O, Yuriko A, dkk. Docosahexaenoic acid content in plasma phospholipids and desaturase indices in obese children. J Atheroscler Thromb 2011;18:345-50.

23. Araya J, Rodrigo R, Videla LA. Increase in long-chain polyunsaturated fatty acid $n-6 / n-3$ ratio in relation to hepatic steatosis in patients with non-alcoholic fatty liver disease. Clin Sci (Lond) 2004;106:635-43.

24. Mager DR, Patterson C, So S. Dietary and physical activity patterns in children with fatty liver. Eur J Clin Nutr 2010;64:628-35.

25. Kleiner DE, Brunt EM. Nonalcoholic fatty liver disease: pathologic patterns and biopsy evaluation in clinical research. Semin Liver Dis 2012;32:3-13.

26. Garaulet M, Pe'rez-Llamas F, Pe'rez-Ayala M, dkk. Sitespecific differences in the fatty acid composition of abdominal adipose tissue in an obese population from a Mediterranean area: relation with dietary fatty acids, plasma lipid profile, serum insulin, and central obesity. Am J Clin Nutr 2001;74: 585-91.

27. Shichun D, Jie J, Wenjun F, Qing S. Does fish oil have an anti-obesity effect in overweight/obese adult? A meta-analysis of randomized controlled Trials. Plos One 2015;10:1-20. 